\title{
Seasonal Incidence of Tobacco Leaf Eating Caterpillar and Leaf Miner of Groundnut (Arachis hypogaea L.)
}

\author{
V.K. Nigude, S.A. Patil, P.B. Mohite and A.S. Bagade*
}

Department of Agril. Entomology, College of Agriculture, Kolhapur, Mahatma Phule Krishi Vidyapeeth, Rahuri-413722, India

*Corresponding author

\section{A B S T R A C T}

\begin{tabular}{|l|}
\hline Ke y w o r d s \\
$\begin{array}{l}\text { Groundnut, } \\
\text { Seasonal incidence, } \\
\text { Spodoptera litura, } \\
\text { Leaf miner }\end{array}$ \\
\hline Article Info \\
\hline $\begin{array}{l}\text { Accepted: } \\
\text { 06 December } 2017 \\
\text { Available Online: } \\
\text { 10 January } 2018\end{array}$ \\
\hline \hline
\end{tabular}

Seasonal Incidence of Tobacco leaf eating caterpillar and Leaf miner of groundnut (Arachis hypogaea L.) was studied during July to October 2016, at Research farm, College of agriculture, Kolhapur. Groundnut crop was infested by Tobacco leaf eating caterpillar (Spodoptera litura Fab.), Leaf miner (Aproarema modicella Deventer). The study revealed that the incidence of Tobacco leaf eating caterpillar started in $3^{\text {rd }}$ week of August; and Leaf miner $1^{\text {st }}$ week of August. The population of Tobacco leaf eating caterpillar (Spodoptera litura), the population started increasing slowly and reached to its peak in the 35th MW corresponding to September $1^{\text {st }}$ week 3.93 larvae/mrl. The population of Leaf miner (Aproarema modicella).The infestation started increasing slowly and reached to its peak in the $34^{\text {th }} \mathrm{MW}$ corresponding to August $4^{\text {th }}$ week 19.00 per cent. The population of Tobacco leaf eating caterpillar was showed negatively non-significant with rainfall and positively significant with temperature and relative humidity. The Leaf miner population was negatively non-significant with temperature and positively significant with relative humidity and rainfall.

\section{Introduction}

Groundnut (Arachis hypogaea L.) is an annual legume crop, also known as peanut, earthnut, monkey- nut and goobers. It forms the world's largest source of edible oil and ranks $13^{\text {th }}$ among the food crops and is also $4^{\text {th }}$ most important oil seed crop of the world.

It is grown in tropical and subtropical countries. Cultivated groundnut has been reported to from South America (Weiss, 2000). It is infested by many insect pests, among them Spodoptera litura (F.) and leaf miner, Aproaerima modicella Deventer are two important defoliators of the crop. Spodoptera is a ubiquitous, polyphagous, multivoltine, lepidopterous pest that feeds on 112 cultivated crops across the world (Moussca et al., 1960). Spodoptera is a destructive pest that damages groundnut crop extensively by defoliating the plants and thus reducing the photosynthetic capacity of the plant.

The Spodoptera moths are found primarily active during night and due to its high mobility, female ovipositing on a wide range 
of host plants, which promotes or even ensures survival of Spodoptera over a broad range of environmental conditions (Chelliah, 1985). The groundnut leaf miner, A. modicella is an oligophagous pest and feeds only on leguminous host plants and a serious pest of groundnut during both rainy and post rainy season in India and on both groundnut and soybean in South and South East Asia. The leaf miner is considered as the most important insect pest of groundnut in India and particularly in rainfed situations (Ayyar, 1963; Nair, 1975; Reddy, 1988).

\section{Materials and Methods}

The experiment was conducted during Kharif 2016 at College of agriculture, Kolhapur to investigate the Seasonal Incidence of Tobacco leaf eating caterpillar and Leaf miner of Groundnut (Arachis hypogaea L.) Variety TAG - 24 was sown under natural conditions without spraying the insecticides in plot size $3.0 \mathrm{~m} \mathrm{x} 1.80 \mathrm{~m}$ with $30 \mathrm{~cm}$ row to row and 10 $\mathrm{cm}$ plant to plant spacing.

The population of $S$. litura and Leaf miner were recorded at weekly intervals during morning hours between 7.00 am to $9.00 \mathrm{am}$ on five randomly selected and tagged in each plot by using sampling techniques given by Yeotiker et al., (2015). For S. litura number of larvae observed per meter row length in each plot was recorded at three places and mean was reported in per meter row length and Leaf miner. Five plants were tagged in each plot. Number of leaflets and damaged leaflets were recorded and presented in the form of per cent infestation.

\section{Results and Discussion}

The mean population of Tobacco leaf eating caterpillar (Spodoptera litura) and Per cent infestation of Leaf miner (Aproarema modicella) has been presented in Table 1.

\section{Tobacco leaf eating caterpillar, Spodoptera litura (Fab.)}

The data presented in the Table 1 and depicted in Figure 2 clearly indicated that the $S$. litura incidence was first appeared in the $33^{\text {rd }} \mathrm{MW}$ corresponding to the August $3^{\text {rd }}$ week with mean population of 3.82 larvae/mrl. The population started increasing slowly and reached to its peak in the $35^{\text {th }} \mathrm{MW}$ corresponding to September 1st week (3.93 larvae/mrl) when the maximum temperature was $28.10 \mathrm{C}$, morning relative humidity 90 per cent and $1.01 \mathrm{~mm}$ rainfall. The population of the $S$. litura declined steadily thereafter from 3.67 at $36^{\text {th }} \mathrm{MW}$ corresponding to September $2^{\text {nd }}$ week.

The correlation coefficient was compared between the $S$. litura population and weather parameters. The analysis indicated in the Table 2 revealed that $S$. litura population was negatively non-significant with rainfall $(-0.33)$ and positively significant with temperature (0.00) and relative humidity (0.52).

\section{Leaf miner, Aproarema modicella (Deventer)}

The data presented in the Table 1 and depicted in Figure 2 clearly indicated that the leaf miner incidence first appeared in the $31^{\text {st }} \mathrm{MW}$ corresponding to the August 1st week with mean infestation of 6.50 per cent. The infestation started increasing slowly and reached to its peak in the $34^{\text {th }} \mathrm{MW}$ corresponding to August $4^{\text {th }}$ week (19.00 per cent) when the maximum temperature was 27.2 0C, morning relative humidity 89 per cent and $27.1 \mathrm{~mm}$ rainfall.

The infestation of the leaf miner declined thereafter from 16.00 per cent at $35^{\text {th }} \mathrm{MW}$ corresponding to September 1st week to 13.00 per cent at $38^{\text {th }}$ MW corresponding to September $4^{\text {th }}$ week. 
Table.1 Seasonal incidence of sucking insect pests in groundnut variety TAG -24 during kharif, 2016

\begin{tabular}{|c|c|c|c|c|c|c|}
\hline SMW & Date & Temperature & Humidity & Rainfall & S.litura & Leaf miner \\
\hline No. & & $\left({ }^{\circ} \mathrm{C}\right)$ & $(\%)$ & $(\mathrm{mm})$ & $(\mathrm{mrl})$ & $\begin{array}{c}\text { (Per cent } \\
\text { infestation) }\end{array}$ \\
\hline 31 & 30 July -5 Aug & 21.75 & 80.00 & 166.7 & 0.00 & 6.50 \\
\hline 32 & 6 Aug-12 Aug & 22.4 & 86.00 & 100.4 & 0.00 & 10.50 \\
\hline 33 & 13 Aug-19 Aug & 23.0 & 78.50 & 16.7 & 3.82 & 18.50 \\
\hline 34 & 20 Aug-26 Aug & 23.0 & 88.00 & 27.1 & 3.84 & 19.00 \\
\hline 35 & 27 Aug-2 Sept & 23.6 & 85.50 & 01.1 & 3.93 & 16.00 \\
\hline 36 & $3 \mathrm{Sept}-9 \mathrm{Sept}$ & 23.25 & 81.50 & 01.9 & 3.67 & 16.50 \\
\hline 37 & $10 \mathrm{Sept}-16 \mathrm{Sept}$ & 23.2 & 74.00 & 17.9 & 2.50 & 14.00 \\
\hline 38 & $17 \mathrm{Sept}-23$ & 22.35 & 81.50 & 44.9 & 0.00 & 13.00 \\
\hline 39 & $24 \mathrm{Sept}-30 \mathrm{Sept}$ & 24.1 & 71.00 & 01.5 & 0.00 & 0.00 \\
\hline 40 & 1 Oct -7 Oct & 23.0 & 75.50 & 02.7 & 0.66 & 0.00 \\
\hline 41 & 8 Oct-14 Oct & 24.25 & 71.00 & 29.9 & 0.33 & 0.00 \\
\hline 42 & 15 Oct -21 Oct & 24.55 & 65.00 & 0.0 & 0.00 & 0.00 \\
\hline 43 & 22 Oct -28 Oct & 23.30 & 58.50 & 0.0 & 0.00 & 0.00 \\
\hline
\end{tabular}

Table. 2 Correlation coefficient between abiotic factors and population of sucking pests of groundnut

\begin{tabular}{|l|c|c|}
\hline Parameters & S. litura & Leaf miner \\
\hline Temperature & 0.00608 & $-\mathbf{0 . 4 1 2 4 9}$ \\
\hline Humidity (\%) & $0.526198^{*}$ & $\mathbf{0 . 7 4 3 6 4 6 *}$ \\
\hline Rainfall (mm) & $-\mathbf{0 . 3 3 7 0 8 9}$ & $\mathbf{0 . 0 5 2 7 7 *}$ \\
\hline
\end{tabular}

* Significant at 5 per cent level.

The correlation coefficient indicated in the Table 2 revealed that leaf miner infestation was negatively non-significant with temperature (-0.41) and positively significant with relative humidity $(0.74)$ and rainfall (0.05).

These results are in line with the findings of Kharub et al., (1993) who reported that the peak incidence of $S$. litura on groundnut appeared after $41^{\text {st }}$ MW having maximum temperature $33.80 \mathrm{C}$ and relative humidity 61 per cent. Similar finding was reported by Yotikar et al., (2015) who reported that the continuous and heavy rainfall received during the season did not allow the population of $S$. litura to build up. Also Kasana et al., (1996) reported that the population of $S$. litura on cauliflower declined in second half of October and he further attributed the fluctuation in the population to unfavourable weather conditions. These findings are in conformity with the results of Pazhanisamy and Hariprasad (2014) who revealed that minimum temperature showed significant positive correlation with incidence of leaf miner.

Similarly, Lewin et al., (1979) reported positive correlation of temperature with leaf miner incidence. Logiswaran and Mohanasundaram (1985) stated that rainfall was not correlated with mean number of larva/plant of A. modicella. Gadad et al., (2013) studied the influence of weather parameters on incidence of leaf miner 
indicated a negative as well as significant relationship with morning relative humidity.

\section{References}

Ayyar, T. V. R. 1963. Handbook of Economic Entomology for South India, Government Press, Madras, pp. 516.

Chelliah, S.L., 1985. The tobacco cutworm, Spodoptera litura problems and prospects of management. Integrated Pest and Diseases management, TNAU, Coimbatore, pp. 139-159.

FAO 2010. FAO Production Year book, Vol. 60.

Gadad, H., Hegde M., and Balikai, R. A. 2013. Seasonal incidence of Spodoptera litura and leaf miner in rabi/summer groundnut. J. Exp. Zool. India, Vol. 16, No. 2, pp. 619-622.

Kasana, A., Matin, M. A. and Hashmi, A. A 1996. Seasonal population fluctuations of Spodoptera litura larvae in cauliflower. PARC, Islamabad, 2nd International Congress of Entomological Sci., March, 19-21. pp. 67-68.

Kharub, R., Singh, S.H., Rohilla, H.R. and Chopra, N. P. 1993. Population dynamics and biology of Spodoptera litura (Fab.) on groundnut Arachis hypogaea Linn. Annl. Biol. Ludhiana, 9: 257-262.

Lewin, H. D., Saroja, R. David, Leela and M. Padmanabhan, M. D. 1979. Influence of sowing time and weather on the incidence of groundnut leaf miner. Indian J. Agric. Sci., 40: 886-891.

Logiswaran, E. and M. Mohanasundaram 1985. Effect of intercropping, spacing and mulching in the control of groundnut leaf miner, Aproaerema modicella Deventer (Gelechiidae: Lepidoptera). Madras Agriculture Journal, 72: 695-700.

Moussa A M, Zather M A and Kothy F., 1960. Abundance of cotton leaf worm, Prodenia litura (F) innrelation to host plants. Host plants and their effects on biology (Lepidoptera: Agrotidae Zanobiinae). Bull. Sec. Ent. Egpt. 44: 241-251.

Nair M R G K 1975. Insect and Mites of Crops in India, ICAR, New Delhi, Pp. 404.

Pazhanisamy, M. and Hariprasad Y. 2014. Seasonal incidence of leaf miner, Aproaerema modicella (Deventer) in groundnut ecosystem in Ariyalur district of Tamilnadu, India. Plant Archives, 14(1): 55-58.

Reddy 1988. The Groundnut, ICAR Publication, pp. 572.

Weiss, E. A. 2000. Oilseed Crops. Publ. by Blackwell Science, London. Pp. 13.

Yeotikar, S. G., More, D. G. and Gaikwad, B. B. 2015. Seasonal incidence of major insect pests of soybean. Indian J. Agric. Sci., 39(4): 341-346.

\section{How to cite this article:}

Nigude, V.K., S.A. Patil, P.B. Mohite and Bagade, A.S. 2018. Seasonal Incidence of Tobacco Leaf Eating Caterpillar and Leaf Miner of Groundnut (Arachis hypogaea L.). Int.J.Curr.Microbiol.App.Sci. 7(01): 562-565. doi: https://doi.org/10.20546/ijcmas.2018.701.067 